This item was submitted to Loughborough's Research Repository by the author.

Items in Figshare are protected by copyright, with all rights reserved, unless otherwise indicated.

\title{
Performing radical democracy
}

PLEASE CITE THE PUBLISHED VERSION

PUBLISHER

Edinburgh University Press

VERSION

AM (Accepted Manuscript)

PUBLISHER STATEMENT

This work is made available according to the conditions of the Creative Commons Attribution-NonCommercialNoDerivatives 4.0 International (CC BY-NC-ND 4.0) licence. Full details of this licence are available at: https://creativecommons.org/licenses/by-nc-nd/4.0/

\section{LICENCE}

CC BY-NC-ND 4.0

REPOSITORY RECORD

Lloyd, Moya S.. 2019. "Performing Radical Democracy”. figshare. https://hdl.handle.net/2134/17501. 


\title{
Chapter Two \\ Performing radical democracy
}

\author{
Moya Lloyd
}

Power is not stable or static, but is remade at various junctures within everyday life; it constitutes our tenuous sense of common sense, and is ensconced as the prevailing epistemes of a culture. Moreover, social transformation occurs not merely by rallying mass numbers in favour of a cause, but precisely through the ways in which daily social relations are rearticulated, and new conceptual horizons opened up by anomalous and subversive practices (Butler 2000a: 14).

It may seem perplexing in a book exploring the politics of radical democracy to have two chapters devoted to the work of Judith Butler for she is hardly known as a democratic theorist. Indeed, a quick search through the indexes to all her singleauthored books reveals the sum total of only one reference to democracy in all nine texts (2004a: 226). ${ }^{1}$ Even extending the remit a bit wider to include references to the writings of, say, radical democratic thinkers such as Laclau and Mouffe, fails to yield much more. They appear in the indexes of just two books (Excitable Speech and Bodies that Matter). ${ }^{2}$ Yet in this chapter, I will argue that Judith Butler is a radical democrat and that she develops her account of radical democracy, in part, out of a critical engagement with the work of Laclau and Mouffe, particularly that of Laclau. Moreover, to make my case, I will be drawing amongst other things on some of the very texts that appear to offer little indexical evidence of Butler's interest in radical democracy. In part I am able to do so because the indexes to Butler's books are highly 
parsimonious: democracy - as both a theory and practice - appears more often than they suggest, though still not on the scale to warrant identifying any of her books as a piece of democratic theory per se. The more important factor, however, is that the concept that I suggest is central to Butler's understanding of radical democracy, what I term universality-to-come (echoing, of course, Derrida's idea of democracy-tocome), becomes increasingly salient in these writings over time.

There are two areas that concern me in this chapter; I have examined the broad terms of Butler's discussions of radical democracy elsewhere (Lloyd 2007a and 2007b). The first relates to the idea of universality-to-come. I am interested here both in the contours of this concept and in how Butler differentiates her approach from that of Laclau, whose own contribution to advancing the debate on radical democracy has been identified by some commentators in terms of its concentration on the universal (Critchley and Marchart 2004: 4). The second area concerns the transfiguration of 'daily social relations' alluded to at the outset of the chapter. Here I focus on samesex marriage. As an issue it illustrates very clearly, I propose, a deconstructive aporia at the heart of Butler's account of radical democracy: a blindness to the state as a possible mechanism for universalisation that is in tension with Butler's characterisation of radical democratic struggles as struggles to resignify the universal (and, most particularly, the human as a universal). As I demonstrate below, an account of radical democracy that does not conceive of the possibility of operating through the state in the advancement of democratic demands is an account that risks abstracting from, and thus neglecting, the specific contexts within which political contestation actually occurs. To contend a priori that the state cannot facilitate democratic demands is not a radical claim per se. The radicalism of any political strategy can 
only be evaluated in situ. For this reason, I will argue, that it is necessary in the light of shifting political circumstances in the US to re-evaluate Butler's assertion that radical sexual politics is best served by rejecting same-sex marriage. ${ }^{3}$

\section{Competing universalities}

Butler develops her account of radical democracy, as noted earlier, in part out of a critical engagement with the work of Laclau and Mouffe. Tellingly, she rejects Laclau and Mouffe's emphasis in Hegemony and Socialist Strategy (1985) on the production of democratic identities as such; queries what she perceives to be their positing of transcendental 'a priori conditions of political articulation itself (across all time and place)' (2000c: 272) as the basis for democratisation; and worries about the hermeneutics of their reading of new social movements as pivotal to democracy. Where she does draw intellectual sustenance for her account of radical democracy is from Laclau's discussion of universality, though as will become clear, hers is a qualified approval of his position.

Over the last thirty years or so, feminists, post-colonialists, communitarians, and poststructuralists have expended considerable energy endeavouring to demonstrate the limited and partial nature of what passes for the universal. The fall of Communism, rise of various nationalisms, and the shift towards multicultural politics (itself fed by the appearance of a constellation of different political movements representing diverse groups) have all contributed in various ways to the problematisation of the universal. Butler was once a vociferous critic of the universal, contending that it was not just 'violent and exclusionary' but also 'totalizing' (2004b: 339). Yet within only a few 
years, she was arguing that an open-ended sense of universality was not only useful for but essential to the radical democratic transformation of society. It is not the reason for this apparent change of heart that concerns me here, though needless to say it should not be construed as signalling a return to old style notions of the universal as predicated on some pre-existing characteristic of humanity. ${ }^{4}$ It is how Butler characterises the relation between universality-to-come and radical democracy that is of interest.

In Contingency, Hegemony, Universality, Butler engages in a debate with Ernesto Laclau and Slavoj Žižek about, amongst other things, the status of the universal. Echoing Laclau (I will set aside Butler's debate with Žižek on this occasion), Butler argues that the 'open-endedness that is essential to democratization implies that the universal cannot be finally identified with any particular content, and that this incommensurability (for which we do not need the Real) is crucial to the futural possibilities of democratic contestation' (2000b: 161). The unrealisability of the universal is precisely what keeps democracy alive. Democratic political struggles arise as a means both of contesting the exclusionary nature of particular universals and of endeavouring to render 'key terms of liberalism', as she puts it, 'more inclusive, dynamic and more concrete' (Butler 2000a: 13; see also Butler 1997a: 160 and 2001: 419). Such struggles are politically potent, then, when they compel a less exclusionary rearticulation of the fundamental assumptions of democracy itself. Butler thus shares with Laclau the idea of the impossibility of a fully realisable universalism - or to use different language, the incompletion of the universal. Significantly, she differentiates her account from Laclau's in two ways. 
First, she returns to Hegel to argue that 'the relation of universality to its cultural articulation is insuperable' (2000a: 24). The universal, she claims, is always already thoroughly cultural, shaped by the customary practices through which it is enacted - a 'given syntax' and 'a certain set of cultural conventions' (Butler 2000a: 35). She thus rejects Laclau's conceptualisation of the universal as being formally empty. Rather the 'universal in culture', as she calls it, always depends on 'decidedly less than universal conditions' for its expression (Butler 1996: 44-5). Second, although seeming to endorse Laclau's claim that it is the incommensurability between the particular and the universal that is central to democratisation, Butler distances herself from what she perceives to be his a priori assumption that the political field is divided between 'modes of resistance that are particular and those that successfully make the claim to universality' (Butler 2000b: 165). The point is not that she queries the interimbrication of universal and particular suggested by Laclau but that she rejects the idea that they are logically incompatible categories (Butler 2000b: 162). Here she draws on Linda Zerilli's discussion of Joan Scott's work on post-revolutionary French feminist politics to make her case (Zerilli 1998: 16). ${ }^{5}$

When Scott explores the universal in relation to feminism, one of the paradoxes she identifies is that of a possible 'undecidable coincidence of particular and universal' within one idea; in this case the term 'sexual difference', which 'can denote the particular in one political context and the universal in another' (Butler 2000a: 33). It can thus stand for women's specificity (a particularism) or for something that is common to all humanity (a universal). Examining the 'particular in its particularity' might reveal, in other words, that 'a certain competing version of universality is intrinsic to the particular movement itself' (Butler 2000b: 166). What sustains 
democratisation for Butler is not a clash between universal and particular, as Laclau maintains but, in a context of deep pluralisation, a clash between particular cultural universals.

The inevitable question raised by this formulation is how best to mediate between competing universals? What kind of radical democratic politics is involved here? The short answer is one of 'establishing practices of translation' amongst conflicting universals so that a non-transcendental commonality can be forged (Butler 2000b: 167; see Lloyd 2007a for a fuller discussion). What does this involve? According to Butler, when a disenfranchised group make a universal demand they commit a performative contradiction: they lay claim to something (a right, an ontology) from which they are constitutively excluded (1996: 48). At that very moment, 'an invocation that has no prior legitimacy can have the effect of challenging existing forms of legitimacy', and open up a new, more universal, form (Butler 1997a:147; see also Rancière 1999). The limited reach of the existing universal is divulged and the universal is thus challenged. In appealing to the universal, the disenfranchised, that is, expose the extent to which the universal rests on particular, exclusionary assumptions about who qualifies as a person having the right to appeal to the universal.

It is not just that those demanding universal rights do not already have them; the real problem is that they are not recognized as possible subjects of said rights in the first place. They thus signify both the limit of the human and thus 'the limit to universalizability' (Butler 1996: 46). The ‘assertion of rights becomes', for Butler therefore, 'a way of intervening into the social and political process by which the human is articulated' (2004a: 33); a way of challenging the norms defining who 
counts as human. And so, a radical democratic politics, oriented towards universalityto-come, is intrinsically tied to 'struggle[s] with the norm' (Butler 2004a: 13): norms defining the human, norms establishing sex and sexual difference, norms defining whose life counts. By disrupting that which is settled and 'known', radical democratic politics opens up space to 'rethink the possible' (Butler 1999a: xx); to contest, in other words, the normative violence that determines who counts. (For more on normative violence see Lloyd 2007a.) What, however, is the relation between struggling with the norm and cultural translation?

The aim of cultural translation is neither to posit an alternative set of a priori universal assumptions about the human nor to attempt to assimilate the excluded to an existing (heteronormative, racially or ethnically framed) conception of the human. There is equally no point in endeavouring to impose a view of the universal on a culture resistant to it. Rather, cultural translation involves an encounter between competing conceptions of the universal, articulated in different languages, that produces a transformation in how the universal is thought. It is a difficult and laborious process. It requires that each of the competing universals 'change in order to apprehend the other' (Butler 2004a: 38), to give up some of their foundational assumptions. This, in turn, demands of radical democratic subjects if not a commitment to, then at least a willingness to undergo, epistemological uncertainty. Drawing inspiration from the work of Chicana feminist Gloria Anzaldùa, Butler commends subjects to 'put our own epistemological certainties into question, and through that risk and openness to another way of knowing and of living in the world to expand our capacity to imagine the human'. And, reading her at her most radical, democratic transformation for Butler can and will occur only when such subjects 
'exist[...] in the mode of translation, constant translation' (Butler 2004a: 228); when they can let go of the comfort of knowing already what the human is - giving up, in other words, the limiting religious, racial or heteronormative frames that presently define the human in order to generate a wider, more uncertain, yet less restrictive conception (Butler 2004c: 89-91).

So, to sum up, radical democratic politics, for Butler: is inherently contestatory and dissonant; operates through practices of cultural translation designed to rework the universal 'from myriad directions' so that it becomes more capacious (Butler 2004a: $224)$; is staged through the appropriation of claims to equality, freedom, justice and rights by the disenfranchised; and is constitutively open-ended. Radical democratic universality is thus always a universality-to-come. Moreover, no $a$ priori assumptions can be made either about the process or conditions of democratisation (articulating the universal and particular), or about its agents (new social movements).

Democratisation is always already culturally articulated: dependent on historically embedded subjects and available political vernacular. For all the strengths of her account, however, when it comes to Butler's discussion of specific examples of radical democratic politics at work, particularly with regard to sexual politics, she introduces a questionable a priori assumption of her own: that civil society is the only appropriate locus for radical democratisation and the production of universals-tocome. (For an exploration of the place of civil society in radical democratic thought see Martin, this volume). 


\section{Restaging the universal - demanding 'love rights'}

Earlier in this chapter, I suggested that as a radical democrat Butler might be understood as arguing for the radicalisation of liberalism - that is, the extension of liberal notions of equality, freedom and so on to more and more areas of social life. I also hinted that she conceives of radical democratic politics in terms of everyday-ness. Finally, I suggested in the introduction to this chapter that democratic politics had been present in her work from at least Gender Trouble onwards. I now want to return to some of these claims. My first contention is that Butler does rather more than seek to democratise the explicit values of liberalism (liberty, equality, justice). In her efforts to argue for an extension of the norms that 'sustain a viable life' to all persons (Butler 2004a: 225) she argues for the necessity to democratise the 'fundamental categories' that organise cultural and social life so as to make them 'more inclusive and more responsive to the full range of cultural populations' (Butler 2004a: 223-4). This is what is required in order to instantiate a 'radical democratic transformation' of society (Butler, 2000b: 147). Although it is not possible to specify all the fundamental categories Butler has in mind in this statement, it ought to be clear from her work to date that it includes sex, gender and sexuality. ${ }^{6}$ Her critique of heteronormativity (begun in the essays leading to the publication of Gender Trouble and continued unabated since) should thus be read, I am suggesting, as an effort to democratise what is understood by sex and sexual difference. Similarly her interventions in the debate surrounding same-sex marriage should be understood as part of an endeavour to develop a more radically democratic formulation of intimate relations. 
One of the third generation rights, or 'love rights' as Robert Wintemute terms them (2005), that has dominated much gay and lesbian campaigning across the globe has been that of same-sex marriage. ${ }^{7}$ This is certainly true of the United States where it has been at the forefront of debates within the gay, lesbian and queer movements since the 1990s. In what follows, I want to explore Butler's somewhat late entry into this debate. Before I do so, however, a little context is appropriate. ${ }^{8}$

In 1993 the Hawaii Supreme Court ruled, in the case of Baehr v. Lewin, that refusing to issue marriage licenses to members of the same sex seemed to be in violation of the equal protection clause of the state's constitution. An evidentiary hearing was ordered at which the state was to be granted the opportunity to show that there were 'compelling state interests' in denying same-sex couples the right to marry. Before that hearing was over, not only had Congress passed and pro-gay President Clinton signed the Defense of Marriage Act (1996), which stipulated that 'the word "marriage" means only a legal union between one man and one woman as husband and wife' ('DOMA', in Baird and Rosenbaum 2004: 290) but the people of Hawaii had voted in favour of a constitutional amendment prohibiting same-sex marriage (1998). What was widely perceived to be a decision paving the way for the legalisation of same-sex marriage in Hawaii (Baehr v. Lewin) turned out to be the start of a battle that divided the gay, lesbian and queer movements as activists contended over whether state-sanctioned same-sex marriage was the right strategy to pursue.

Since then much has happened: the Massachusetts Supreme Court in Goodridge v. Department of Public Health (2003) ruled in favour of same-sex marriages, thus legalising them; in 2004 the mayor of San Francisco, Gavin Newsom, started 
authorising same-sex marriages on the grounds that failure to do so was discriminatory under the terms of the Californian Constitution only to have his decision overturned that same year by the California Supreme Court (with some four thousand marriages voided as a consequence); and in 2006 President George W. Bush attempted, unsuccessfully, to fulfil his election promise to amend the US Constitution via the Marriage Protection Amendment. Had it succeeded, this amendment would have secured the heteronormativity of marriage in law. ${ }^{9}$

Given the characteristics of radical democracy outlined in the introduction to this book, from a theoretical perspective at least, one might expect a radical democrat - or, at least, a radical democrat who conceives of the expansion and contestation of rights as a radical move (and I will return to this below) - to embrace the campaign to extend the right to marry to gays and lesbians. First, it seeks to extend a universal right, indeed a human right, to a constituency denied it. ${ }^{10}$ The campaign for same-sex marriage might be understood, therefore, as not only endeavouring to secure equal civil and human rights for gays and lesbians but also as a means of contesting the nature of, and thus of rethinking, marriage and sexual citizenship in nonheteronormative terms. Next, the demand appears to involve a performative reconstitution of the demos. Just as in the case of Jeanne Deroin, the excluded (gays and lesbians) seize the very language of entitlement that de-recognizes them (in this case, that of marital entitlement) and claim to be covered by it, effecting what Butler terms a 'performative contradiction' (Butler 1996: 48). To paraphrase Rancière, we might say that gays and lesbians reveal themselves as necessarily included in the populous enjoying marital rights while being at the same time radically excluded from that populous. In the process, they restage it. Next, we might also read this campaign 
as evidence of what Connolly calls 'pluralist enactment' (1995: xiv); that is, part of the forging of a new pluralising identity. Here the demand for same-sex marriage is one that disturbs established identities, challenging them to revise the terms of their own self-recognition, and one that shatters the terms of normality that define the current state of pluralist existence.

Moreover, with reference to Butler's own discussion of universality, there seems to be evidence to support the case that this campaign is a radically democratic one. Given that the right to marry is predicated upon a heterosexual subject (and, even then, only some heterosexual subjects), the campaign discloses the extent to which the hegemonic universal is haunted by, indeed depends on, the particular. If the radical democratisation of social relations involves the contestation and resignification of the universal in a more inclusive manner, then the gay and lesbian demand to wed appears to do precisely that: to extend a right to more and more people regardless of sexual orientation. Too, there are competing universals at stake in the political debates that have raged: between those who consider the universality of marriage rights as indelibly tied not just to heterosexuality but to heteronormativity and those who see the right to marry as a human right that ought to be open to all humans, including gay and lesbian humans. It does not seem too far-fetched to contend that at issue in this political spat is one of translation as Butler describes it: where translation discloses the 'alterity within the norm' (1996: 50) and, in so doing, divulges the limited reach of the universal. Yet, as Butler's interventions in the debate around same-sex marriage make clear, she is profoundly sceptical of it as a goal. First, I want to consider what it was that was deemed problematic about same-sex marriage from a movement 
perspective and second, how this squares with the account of radical democracy Butler articulates.

\section{The trouble with same-sex marriage}

The critics, many of them queer theorists and activists, who began developing their critique of same-sex marriage in the 1990s focused on a number of arguments, all of which Butler more or less reprises in her own work (see Warner 1999 chapter 3 by way of comparison). Before we consider them it is important, I think, to point out that these arguments were articulated as part of an immanent debate within the gay and lesbian movement, directed at those in its mainstream who had embraced same-sex marriage. As such, their purpose was to attempt to (re-)galvanise a more radical gay and lesbian and/or queer sexual politics. So, what was the gist of this movement-based rejection of same-sex marriage?

The first claim levelled was that the campaign sought to naturalise and thus to normalise marriage and, in so doing, was merely seeking to assimilate the 'shiny, new gay citizen' (Butler 2004b: 150) to an existing straight norm. Such assimilation reinforced another problematic feature of marriage: its construction as the necessary site for the attainment of particular rights and benefits: for instance, the rights to adopt, to inherit, to gain executive control of medical decision-making, to various tax advantages and to spousal support. ${ }^{11}$

Next, it was charged, the campaign was less to do with 'recognition' than with 'regulation', as Claudia Card comments (2007: 24; see also Butler 2004a: 102-30). 
That is, because marriage is a state-sanctioned contract designed to organise intimate life it is never - and never can be - simply a private arrangement between two consenting adults. It requires, as Michael Warner, one of the foremost queer critics of same-sex marriage, points out 'the recognition', indeed enforceable recognition, 'of a third party' (1999: 117): the state (sometimes via one of the organs it authorises to conduct marriage ceremonies). Seeking to extend marriage to same-sex couples would thus further bolster the power of the state to police intimate life, in the process allowing it to determine who counts and, as just observed, who gets what in the way of privileges. Because marriage is a form of 'selective legitimacy', sanctifying 'some couples at the expense of others' (Warner 1999: 82; Card 1996), it is not only able to deny the legal benefits attaching to marriage to those who reject it but it also guarantees that the intimate relations of those who refuse marriage are less valued less legitimate - than those of their married (gay or straight) peers (Butler 2000b: 1756 and 2004a: 109). In this respect, same-sex marriage entails a failure of universalisation.

Perhaps the most trenchant criticism, however, had to do with the impact of the focus on same-sex marriage on gay and lesbian politics in general, and on queer politics in particular. As Warner notes, although the issue of same-sex marriage was raised in the 1970s, lesbian and gay groups did not make its legalisation central to their political demands until the 1990s. In fact, for the most part the movement regarded marriage as a deeply problematic institution: oppressive, patriarchal and a way of mainstreaming gays and lesbians (Ettelbrick [1989] 2004). Instead, it sought to find ways to affirm gay culture and identity and to validate alternative expressions of desire and of forms of relationship and family life. From the 1970s to the 1990s, as Warner remarks, what 
dominated was 'an ethical vision of queer politics centred on the need to resist the state regulation of sexuality' (1999: 88; see Butler, 2000b: 176). This was an antinomian politics centred on politicising sexuality. And, of course, Gender Trouble can be seen as articulating this trend with its critique of heteronormative constructions of sex, gender, sexuality and desire. Focusing on questions of who may marry and, when allied to questions of kinship, of who is entitled to conceive and raise children (Butler 2004a: 130) as the mainstream lesbian and gay movement has done signals, therefore, that a major reorientation of gay and lesbian politics has taken place and one that troubles both Warner and, more recently, Butler.

As noted earlier, Butler reiterates the critique of same-sex marriage advocated by the likes of Ettelbrick and Warner. How, though, does this critique fit with her account of radical democracy? At best, it seems, same-sex marriage symbolises a 'contested zone' of gay and lesbian democratic politics (Butler 2000b: 161): one that divides the movement. Is there a policy, however, that from a queer perspective might capture more fully the radically universal and thus democratic potential of gay, lesbian and queer politics than same-sex marriage has done? Clearly, one fault-line in the marriage campaign identified by Butler (and others) concerns the yoking of marriage to a set of entitlements. One option she (like others) considers is thus to delink marriage and the said bundle of rights and privileges: to open up rights to adoption or reproductive technology to those in non-heteronormative and non-marital alliances (see also Card 2007 and Ferguson 2007). That way, marriage would not be the precondition for said privileges. Instead they would simply accrue to individuals independent of the type of relationship they were in. 
The more important element of Butler's argument in my view, however, concerns the site of democratic struggle. It is the fact that same-sex marriage is 'a project of litigation' (Warner 1999: 85) that bothers her. As the opening paragraph of Antigone's Claim makes clear: Butler is resistant to "contemporary efforts to recast political opposition as legal plaint and to seek the legitimacy of the state in the espousal of [political] ... claims' (2000e: 1). And same-sex marriage is no different. Her reasons are clear: litigation confers additional legitimacy and regulatory power on the state and leads to the view that the state is the 'necessary venue for democratization itself' (2000b: 176). This is why in contrast to some other queer critics, Butler I would suggest is critical not only of same-sex marriage but equally so of other forms of legal partnership arrangement: because they rest on state-approved and thence regulatory and normalising legal contracts (2004a: 109).

Against this juridical emphasis, she proposes that 'the only possible route for a radical democratization of legitimating effects' is to displace marriage and allow a 'return to non-state-centred forms of alliance that augment the possibility for multiple forms on the level of culture and civil society'. It is, in other words, more radical and democratic to refuse marriage - indeed, to let the norm of marriage shrivel and die and to support the alternative relationship (both intimate and kinship) forms that already exist in civil society. That way, she suggests, 'the hope would be, from the point of view of performativity, that the discourse [of marriage] would eventually reveal its limited reach, avowed only as one practice among many that organize human sexual life' (Butler 2000b: 177). This political stance reinforces the contention noted in the epigraph to this chapter: that radical democratic transformation is facilitated by the restaging of quotidian social relations, which themselves lead to the 
emergence of 'new conceptual horizons'. The presence of a multiplicity of nonmarital relations in civil society itself suggests that there already exist alternative ways of thinking about - of conceptualising - sexuality, sexual alliances and kinship relations to the ideal touted by the pro-marriage lobby (gay and/or straight).

\section{To wed or not to wed: that is the question}

At the heart of Butler's scepticism about same-sex marriage is the belief that this policy will not, indeed cannot, bring about social change in the sense of securing the democratisation of intimate relations. Central to this, as noted, is Butler's critique of the place of the state in this campaign. In this section, however, I want to cast doubt on her interpretation of same-sex marriage given the way that the US political context has changed since the 1990s when the internecine debate concerning same-sex marriage emerged within the gay, lesbian and queer movement to now, towards the end of the first decade of the twenty-first century, when the opposition to same-sex marriage from all quarters (including, in particular, conservative forces) has intensified; from a time when Michael Warner could write that 'the only people arguing against gay marriage, it seems, are those homophobic dinosaurs - like [Representative Henry] Hyde, or Senator Jesse Helms, or the feminist philosopher Jean Bethke Elshtain' (1999: 83) to a time when an increasing number of US states have acted - and are continuing to act - to ban same-sex marriage. ${ }^{12}$

The critique I advance will draw on Butler's own theorisation of radical democracy. My purpose is not, however, to advocate same-sex marriage per se; I remain ambivalent about it as a radical political project. What I seek to expose, rather, is a 
tension at the heart of Butler's account of radical democracy with respect to the state, which compels her to view it ipso facto as a hindrance to democratisation, a position that consequently produces a certain disabling inattentiveness on her part to political context. In short, I will suggest, that Butler's critique of same-sex marriage needs amending in the light of the political developments that have taken place since gays and lesbians first began demanding the right to marry. Not only has the 'marriage issue has been used to reentrench homophobia' since then but, as Claudia Card observes, it has given new life to the forces of conservatism determined to preserve the sanctity of heterosexual marriage (2007: 33). Before I consider same-sex marriage in terms of the current US political context, I need to demonstrate that the theoretical resources are present in Butler's work to show that marriage is potentially resignifiable. I thus return to the idea of performative contradiction and the radical democratic potential that, according to Butler, inheres in it.

One of the examples that Butler cites, and cites frequently, is Paul Gilroy's discussion in The Black Atlantic (1993) of the relation between slavery and modernity. Butler is interested in Gilroy's Hegelian contention that, far from being excluded from modernity as so often claimed, the enslaved have been 'able to appropriate essential concepts from the theoretical arsenal of modernity to fight for their rightful inclusion in the process' (Butler 2001: 420) and, as such, historically slavery operated as a force of modernisation. As Butler parses it, when slaves took up the terms of modernity (equality, justice and so forth), they revised them, a process that had 'radical consequences' for the development of a non-ethnocentric understanding of modernity. From this she concludes, in an argument that proved pivotal to Excitable Speech, that the role of 'reappropriation is to illustrate the vulnerability of these often 
compromised terms to an unexpected progressive possibility', the creation (in this particular case) of a 'more radically democratic modernity' (Butler 2001: 421, my emphasis; and Butler 1997a: 160-1).

For all its structural similarity to the case of slavery and modernity, however, Butler disallows same-sex marriage this radical outcome. Yet, gays and lesbians in demanding a right from which they have been constitutively excluded are performing a contradiction not dissimilar to that performed by slaves. ${ }^{13}$ Going further, in so doing they recompose the demos, extending its terms to include some of those conventionally denied entry to it. For all this, however, their performative contradiction apparently does not, in Butler's eyes, produce the same kind of radical resignification that slaves effected with respect to the core ideals of modernity. Theirs opened up a different future for ideals like freedom, justice, and equality; theirs unsettled the polity (Butler 1997a: 161). By contrast, same-sex marriage she suggests does not. The question is why?

There is ample evidence throughout her work, and here Excitable Speech is exemplary, to demonstrate both that Butler regards rights discourse as having potentially radically democratising effects, because of its amenability to resignification, and yet sees the turning of such rights into justiciable or legal rules (their positivisation) as a problem. ${ }^{14}$ It appears as if the radical democratic moment in the restaging of rights discourse is the moment when a rhetorical or symbolic claim is made on specific rights. At such times, Butler interprets them admitting 'a sense of difference and futurity' into the polity (1997a: 161). By contrast, Butler views, almost without fail, the demand to have such rights recognised in law as an invitation to the 
state to increase its regulatory and normalising powers and thus as working against democratisation. This exposes, I propose, a tension in her account of radical democracy. In the first instance, the appropriation and recycling of rights discourse suggests the possible constitution of a newer, more-encompassing universal. Not so the second instance, for state recognition of such rights, it seems, is not an appropriate means of instating a universal. For the state is divisive: a means of policing and controlling particular sectors of the population.

Given this, one might wonder what place rights (symbolic or legal) have in radical democratic politics. In what sense(s), if any, is it sufficient simply to lay claim to a particular right without the eventual prospect of that right being codified in some way? Is it enough just to make a claim on legitimacy without requiring its conversion into something enforceable? The plot only thickens when we recall that Butler is opposed to marriage because it is the only way to access particular rights. She does not, on this occasion at least, appear to doubt or to contest the need for such rights. This only begs another question, however, that if rights (of adoption, inheritance and so on) are to be meaningful politically then how are they to be secured, if not by the state? And if, paradoxically, it is the state that is to guarantee these rights, then what is it at such times that prevents it from fortifying its own power?

Let us assume, for a moment (and perhaps against our better judgement), that rights have a place in radical democratic politics (see also Chambers 2004). In this context, is there any way of viewing a right to same-sex marriage as contributing in a radical democratic sense to the transformation of intimate alliances? That is, is there a way that it might aid in the articulation of a more inclusive universal. Taking my lead from 
Butler, I want to suggest there is. It concerns the way that positing a less exclusive universal requires struggle with the norm. I want to return, therefore, to the theme of heteronormativity, which Butler did so much to challenge in works such as Gender Trouble and Bodies that Matter. I want to suggest that in reading same-sex marriage as operating simply to assimilate gays and lesbians to an existing norm, Butler downplays the extent to which same-sex marriage has the potential in the present context to contest - and resignify - the heteronormativity of that norm.

Heteronormativity is a regulatory practice made up of/operating through institutions, modes of understanding, norms and discourses that posits heterosexuality as natural to humanity. In this normative regime, sex, gender and desire are assumed to be connected in a specific way: that gender follows from sex and that desire follows from sex and gender. Clearly if any institution symbolises heteronormativity, it is marriage. Masculine man weds feminine woman in order to reproduce a version of the mommydaddy-me family so beloved of psychoanalysis. It is evident that one of the effects of the demand for marriage between two people of the same sex in a context where that is prohibited is to expose the heteronormativity of marriage. It makes visible, that is, the fact that marriage is predicated on heterosexual norms and that so too are the benefits accruing to it (the rights mentioned so often above). To demand that gays and lesbians be allowed to marry partners of the same sex when same-sex marriage is largely impossible, as it is presently in the US (and where it may yet become unconstitutional), poses both a direct and, possibly, a necessary challenge to this normative gender order. It threatens to subvert it by divulging the heterosexual presumption underpinning marriage and, consequently, in making it visible opens it 
up to deconstruction. The heterosexuality of marriage can no longer be tacitly assumed or taken for granted. ${ }^{15}$

In Butler's terms it is, of course, the very performativity of marriage that facilitates this process of subversion - the fact that the saying ('I do') is a doing but a saying and doing that are themselves always already citational (based on repetition). Recall that in her discussion of hate speech, it is the citationality of language that Butler regards as creating the space for a 'counter-mobilization' - when a term or practice is appropriated and made to resignify in mutinous fashion (1997a: 163). The call to legalise same-sex marriage - to resignify it beyond the heteronormative frame - is surely, given Butler's terms, a potential example of a counter-mobilisation. If marriage is, after all, reiterable in an insurrectionary fashion, as Butler must allow given the parameters of her own theory (and as seemed to be the case when in a succession of two-minute ceremonies same-sex couples lined up to be married in San Francisco's City Hall in February 2004), then what is to stop gay marriage in certain contexts contributing to the 'democratic cultivation of alternative sexualities' (Warner 1999: 90) that queer thinkers and activists like her press for? Why not draw a similar conclusion to conservative thinker, Stanley Kurtz when he argues that:

Once we say that gay couples have a right to have their commitments recognized by the state, it becomes next to impossible to deny that same right to polygamists, polyamorists, or even cohabiting relatives and friends. And once everyone's relationship is recognized, marriage is gone, and only a system of flexible relationships is left (Kurtz cited in Ashbee, 2007: 102)? 
What if state recognition were to transfigure marriage into a system of flexible arrangements 'linking two or three, or more individuals (however weakly and temporarily) in every conceivable combination of male and female' (Kurtz cited in Ashbee, 2007: 102) then, perversely, might it not be the state itself that delivers (rather than hinders) the universalisation of 'legitimating effects' that Butler yearns for and the state that articulates a more encompassing universal?

The rub is, of course, that in the world of radical democracy there are no guaranteed outcomes or certainties of any kind. We thus cannot say for sure that same-sex marriage will contribute to a more radically democratic formulation of sex and sexual difference (cf. Butler 2000b: 147). But equally we cannot say that it will not contribute in this way. The best that can be deduced is that subversion of any kind only produces 'the kind of effect that resists calculation' (Butler 1993: 29; see also Lloyd, 2005a: 143-6; Chambers 2007b). What is important, however, and what Butler under-estimates, is the political context within which such allegedly subversive activity takes place.

\section{Conclusion}

We have seen in this chapter that Butler associates the project of radical democracy with the production of a more inclusive universal-to-come. When there is a prospect that this universal will be articulated through the state, when, that is, it appears that recognition is to be universalised through a framework of legal rights, Butler baulks at it. This is nowhere more apparent than in her evaluation of same-sex marriage as a political strategy. The problem, for her, concerns what it means to be legitimated by 
the state. It is not just that one is, as a consequence, subject to selective legitimation (to borrow Warner's phrase). It is not even that it makes marriage into the mechanism, par excellence, through which legitimacy will be conferred. It is simply the fact that the state does the legitimating. Here Butler assumes, in my view, that the state always already has an investment in practices of 'social abjection' (2004a: 112) whereby it instates hierarchies that divide the licit from the illicit; the legitimate from the illegitimate; where, in short, it establishes and maintains the conditions of cultural possibility and impossibility for gendered subjects. Some subjects become 'intelligible' within its terms; others remain - or are constituted as - unintelligible. I do not doubt that the state does this - on occasion, even on many occasions. What I question is whether this is all that it does and whether, as a consequence, daily social relations can only be radically reconfigured in a more democratic (universalising) direction in civil society as Butler surmises. After all, what is it about civil society that better guarantees - for surely, given that too is striated by power relations, it cannot fully guarantee - that the universals produced there will operate in a less regulatory, less normalising fashion than those articulated through the state?

If the goal of radical democracy is to struggle with norms that abject, discipline and regulate particular populations in order to recompose those norms in less violent ways, then surely that struggle should take place wherever those norms operate, including in and through the state. To maintain a priori and in advance that one site ought to be disavowed as a site of political intervention or democratisation seems to me to be highly problematic. The implication that 'eliminating state-sanctioned marriage altogether' (Chambers 2007b: 675) is more subversive of heteronormativity at the level of public policy than seeking same-sex marriage, as Butler implies, is fine 
if we see marriage as intrinsically and irrevocably heteronormative whatever the context. If, however, we allow that marriage itself can be resignified (and as extensively as Kurtz implies), as I suggest Butler must given her own theoretical assumptions, then the case against the current state-oriented political campaign for same-sex marriage carries less weight. ${ }^{16}$

The fact is that both options - refusing marriage and contending for its legal resignification - represent competing ways of intervening in the political social and cultural practices through which humans are constituted. They are both modes of radical democratic struggle with norms. Determining which the more appropriate strategy is depends on the (contingent) political conditions of the day. Opposing same-sex marriage in order to re-radicalise gay and lesbian politics when there exists a broad consensus in its favour is very different to opposing it where the state and other institutions, including the church, have acted in concerted fashion to retrench the heteronormativity of marriage and where same-sex marriage is officially disallowed. The radicalism of same-sex marriage as a policy depends on the context in which it is articulated. That Butler appears not concede this in her comments on the state reveals a blind-spot in her theory in terms of the state's possible role in restaging the universal-to-come; a blind-spot that leads her, moreover, to neglect the (shifting) circumstances in which democratic politics actually occurs.

\section{Notes}

\footnotetext{
* Thanks are due to both Adrian Little and Sam Chambers for their excellent
} 
comments on earlier versions of this chapter. You will both see where you have influenced me and where not!

${ }^{1}$ By all of her books I mean all her single authored books from Subjects of Desire through to Giving an Account of Oneself. This excludes Contingency, Hegemony, Universality, the text Butler co-authored with Ernesto Laclau and Slavoj Žižek. The fact that it does not contain an index, of even the most economical kind, will serve as no defence here. Contingency is important to the development of Butler's theory of radical democracy, not least since it is here that she sets out one of her more elaborated discussions of universality. It should not be read, however, as marking a break in her work - evidence perhaps of her conversion to radical democracy. The politics of everyday life has already been explored extensively in her earlier works. ${ }^{2}$ There is one reference to Hegemony and Socialist Strategy in Excitable Speech (Butler 1997a: 177 n. 3), with a further seventeen references to Laclau and Mouffe in Bodies that Matter, though in this latter case there are duplicate entries for Laclau and for Mouffe (since the text in question tends to be their jointly authored book, Hegemony and Socialist Strategy). In this case, the number of references might justifiably be halved.

${ }^{3}$ Claudia Card who is, like Butler, fervently in favour of the deregulation of marriage notes, by contrast, that changes in the political scene since 2004 'may call for some modification in, or qualification or clarification of [her]... stance' (2007: 32). ${ }^{4}$ In 'Left Conservatism' (1998) Butler gives some indication of her reasons for turning to the universal. 
${ }^{5}$ In addition to Zerilli, Butler also draws on Hegel and his idea of competing conceptions of universality. I have already explored Butler's debt to Hegel at length elsewhere (Lloyd 2007a) so will not reprise those arguments here.

${ }^{6}$ We might, of course, regard heteronormative sex and sexual difference as intrinsic to the liberal agenda; that, however, is part of another story for another time and place. ${ }^{7}$ The first two generations are 'basic rights' and 'sex rights' (Wintemute 2005). ${ }^{8}$ Much has been written about these topics. My account draws on the following: Warner, 1999; Card, 1996, 2007; Chambers 2003, 2007b; Baird and Rosenbaum 2004; Sullivan 2004; Ashbee 2007; Ferguson 2007; Robson 2007.

${ }^{9}$ I am indebted to Samuel Chambers for this point. The key section of the proposed amendment (section 2) reads: 'Marriage in the United States shall consist only of the union of a man and a woman. Neither this Constitution, nor the constitution of any State, shall be construed to require that marriage or the legal incidents thereof be conferred upon any union other than the union of a man and a woman.' In the most recent attempt in 2006 to pass it the amendment failed to secure the necessary twothirds majority in Congress.

${ }^{10}$ The right to marry is enshrined in the Universal Declaration of Human Rights in article 16, section 1, where it states: 'Men and women of full age, without any limitation due to race, nationality, or religion, have the right to marry and to found a family.' On same-sex marriage as a human right see Wintemute 2005 and Card 2007. ${ }^{11}$ Further discussion of the menu of rights that attach to marriage can be found in Warner (1999): 118-9. See also Card 2007.

${ }^{12}$ Florida is a case in point where moves are afoot to include a constitutional amendment banning same-sex marriage on the ballot in November 2008. 
${ }^{13}$ It is important, of course, not to overstate the parallels. For a brief consideration of the class dimensions of the campaign for gay marriage see Goldstein ('Foreword' to Graff 2004) and Warner (1999).

${ }^{14}$ Resignification itself is neither inherently radical nor democratic. Rather it facilitates the development of a more radical democracy by unsettling existing norms and allowing for their recomposition.

${ }^{15}$ This is explicitly not to say, however, that were same-sex marriage to be made legal that it would remain, by definition, a radical practice. Arguably, it is the demand for the right to marry that is radical (in particular contexts).

${ }^{16}$ For an account of how marriage has been resignified historically see Graff 2004. 